\title{
Assessing the effectiveness of specially protected areas for conservation of Antarctica's botanical diversity
}

\author{
Kevin A. Hughes, ๆ Louise C. Ireland, Peter Convey, and Andrew H. Fleming \\ British Antarctic Survey, Natural Environment Research Council, High Cross, Madingley Road, Cambridge, CB30ET, United Kingdom
}

\begin{abstract}
Vegetation is sparsely distributed over Antarctica's ice-free ground, and distinct plant communities are present in each of the continent's 15 recently identified Antarctic Conservation Biogeographic Regions (ACBRs). With rapidly increasing buman activity in Antarctica, terrestrial plant communities are at risk of damage or destruction by trampling, overland transport, and infrastructure construction and from the impacts of anthropogenically introduced species, as well as uncontrollable pressures such as fur seal (Arctocephalus gazella) activity and climate change. Under the Protocol on Environmental Protection to the Antarctic Treaty, the conservation of plant communities can be enacted and facilitated through the designation of Antarctic Specially Protected Areas (ASPAs). We examined the distribution within the 15 ACBRs of the 33 ASPAs whose explicit purpose includes protecting macroscopic terrestrial flora. We completed the first survey using normalized difference vegetation index (NDVI) satellite remote sensing to provide baseline data on the extent of vegetation cover in all ASPAs designated for plant protection in Antarctica. Large omissions in the protection of Antarctic botanical diversity were found. There was no protection of plant communities in 6 ACBRs, and in another 6 , $<0.4 \%$ of the ACBR area was included in an ASPA that protected vegetation. Protected vegetation cover within the 33 ASPAs totaled $16.1 \mathrm{~km}^{2}$ for the entire Antarctic continent; over half was within a single protected area. Over $96 \%$ of the protected vegetation was contained in 2 ACBRs, which together contributed only $7.8 \%$ of the continent's ice-free ground. We conclude that Antarctic botanical diversity is clearly inadequately protected and call for systematic designation of ASPAs protecting plant communities by the Antarctic Treaty Consultative Parties, the members of the governing body of the continent.
\end{abstract}

Keywords: Antarctic Conservation Biogeographic region, Antarctic Specially Protected Area, climate change, human impacts, normalized difference vegetation index, remote sensing, vegetation

Evaluación de la Efectividad de las Áreas Protegidas Especialmente para la Conservación de la Diversidad Botánica de la Antártida

Resumen: La vegetación se encuentra distribuida escasamente sobre el suelo libre de bielo de la Antártida y están presentes distintas comunidades vegetales en cada una de las 15 Regiones Biogeográficas de Conservación Antártica (RBCA) identificadas recientemente. Con un rápido incremento de la actividad humana en la Antártida, las comunidades de plantas terrestres están en riesgo de ser dañadas o destruidas por el pisoteo, el transporte terrestre, la construcción de infraestructura y el impacto de las especies introducidas por el hombre, así como por presiones incontrolables como la actividad del lobo marino antártico (Arctocephalus gazella) y el cambio climático. Bajo el Protocolo sobre la Protección Ambiental al Tratado Antártico, la conservación de las comunidades vegetales puede promulgarse y facilitarse por medio de la designación de las Zonas Antárticas Especialmente Protegidas (ZAEP). Examinamos la distribución dentro de las 15 RBCA de las 33 ZAEP cuyo propósito explícito incluye la protección de la flora macroscópica terrestre. Completamos el primer censo con el uso de teledetección satelital del índice de vegetación de diferencia normalizada (IVDN) para proporcionar el punto de referencia de datos sobre la extensión de la cobertura vvvegetal en todas las RBCA designadas para 
la protección de plantas en la Antártida. Se encontraron grandes omisiones en la protección de la diversidad botánica de la Antártida. No bubo protección en las comunidades vegetales de seis RBCA y en otras seis, $<0.4 \%$ del área de la RBCA estuvo dentro de una ZAEP que protegía a la vegetación. La cobertura de vegetación protegida dentro de las 33 RBCA tuvo un total de $16.1 \mathrm{~km}^{2}$ de todo el continente antártico; más de la mitad se ubicó dentro de una única área protegida. Más del 96\% de la vegetación protegida se encontró en dos RBCA, las cuales en conjunto contribuyen con sólo el 7.8\% del suelo libre de bielo del continente. Concluimos que la diversidad botánica de la Antártida está claramente mal protegida y requiere de una designación sistemática de ZAEP que protejan las comunidades vegetales por parte de las Partes Consultivas del Tratado Antártico, los miembros del cuerpo de gobierno del continente.

Palabras Clave: cambio climático, impactos humanos, índice de vegetación de diferencia normalizada, Región Biogeográfica de Conservación Antártica, teledetección, vegetación, Zona Antártica Especialmente Protegida

\section{Introduction}

The spatial extent of terrestrial habitats in Antarctica is very limited. Only around $0.34 \%$ of the overall continental area is ice-free, whereas the proportion is slightly greater on the Antarctic Peninsula and offshore islands ( 3\%). The remainder is permanently covered by snow or ice (Convey et al. 2009). The total area of ice-free ground in Antarctica is approximately $44,000 \mathrm{~km}^{2}$. About $10 \%$ of this is contributed by the high latitude frigid deserts of the McMurdo Dry Valleys of Victoria Land (Levy 2013), and much of the remainder is formed by inland nunataks (i.e., small areas of rock emerging above ice sheets and glaciers) and high altitude mountain ranges. Therefore, the majority of ice-free ground on the continent is barren of macroscopic organisms, and visually obvious terrestrial biota is restricted predominantly to coastal areas, including along the northern and western Antarctic Peninsula, the archipelagos of the Scotia Arc, and a few ice-free oases along the East Antarctic coastline.

Biodiversity in even the richest terrestrial environments is low relative to other areas of the world. Primary producers are predominantly cryptogams (mosses, liverworts, and lichens; only 2 native vascular plants are present), and there is a significant microflora of fungi, cyanobacteria, and algae (Laws 1984; Smith 2003; Convey 2013). Bryophytes and phanerogams occur primarily along coasts, and inland continental and higher elevation sites host predominantly lichen and microbial communities (Peat et al. 2007). In general, other than the McMurdo Dry Valleys, terrestrial areas are mostly small in extent and isolated and may be separated by ice or ocean on scales up to hundreds of kilometers (Bergstrom \& Chown 1999; Convey 2013). This has had important implications for the rate and effectiveness of colonization processes in the region and has led to extensive and long-term evolutionary isolation (Convey et al. 2008; Pisa et al. 2014), which, combined with variation in local and regional growth conditions, has contributed to the development of spatially distinct biogeographic patterns across the continent (Øvstedal \& Smith 2001; Chown \& Convey 2007; Ochyra et al. 2008). Using detailed multivariate statistical analyses of all spatially explicit terrestrial biodiversity data currently available, Terauds et al. (2012) identified 15 biologically distinct ice-free Antarctic Conservation Biogeographic Regions (ACBRs) across the Antarctic continent and Antarctic Peninsula. Identification of these regions has provided a more formal structure upon which conservation planning and action can be developed within the governance mechanisms of the Antarctic Treaty System (ATS).

Human activity in Antarctica, predominantly involving national governmental operators and the tourism industry, is growing rapidly (Tin et al. 2014). For logistical reasons, coastal locations are favored for tourist visits and research activities, including construction of stations and other logistical facilities of national Antarctic programs. These activities can result in direct damage or destruction of terrestrial habitats during visitor landings, overland transport, infrastructure construction, and ongoing operation of the facility (e.g., Tin et al. 2009; Chown et al. 2012; Braun et al. 2014) (Fig. 1). Changes in natural colonization and human-assisted colonization by new species are also likely to have negative impacts on indigenous flora and communities (Frenot et al. 2005; Hughes \& Convey 2010). Other less controllable pressures on vegetation include increased trampling by expanding fur seal (Arctocepbalus gazella) populations in the Antarctic Peninsula region (Smith 1988; Favero-Longo et al. 2011) and the direct effects of climate change, which tend to increase vegetation cover and species diversity (Fowbert \& Smith 1994; Smith 1994).

Several global biodiversity conservation goals have been proposed in recent years. Most recently, the updated Targets 4 and 5 of the Global Strategy for Plant Conservation (GSPC), adopted initially as a program under the Convention on Biological Diversity (CBD) called, respectively, for effective conservation of at least $15 \%$ of the world's ecological regions and protection of $75 \%$ of the most important areas for plant diversity by 2020 (UNEP 2010a). In parallel, Aichi Biodiversity Target 11 of the CBD Strategic Plan for Biodiversity 2011-2020 calls for at least $17 \%$ of terrestrial and inland water, including areas that are ecologically representative, to be conserved and effectively managed by 2020 (UNEP 2010b). Although most Antarctic Treaty Parties are 

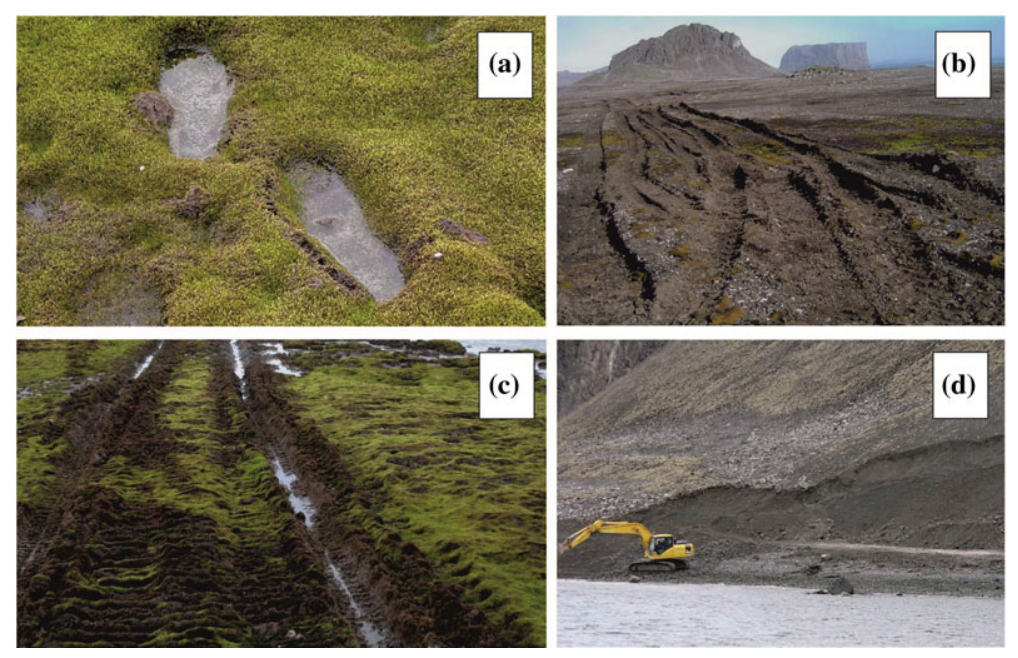

Figure 1. Damage to Antarctic vegetation on Fildes Peninsula, King George Island, South Shetland Islands, from buman activities at different spatial scales: (a) footprints in moss (photo by C. Braun), (b) vebicle tracks over vegetated ground away from the designated road network (photo by O. Mustafa), (c) tracks from all-terrain and tracked vehicles in moss (photo by C. Braun), and (d) quarrying that has damaged lichen growing on a storm petrel breeding ground (photo by H.-U. Peter). Permission for use of these images was granted by H.-U. Peter, Institute of Ecology, Friedrich Schiller University, Jena, Germany. signatories to the CBD, the Convention, and by default the aforementioned biodiversity targets, does not apply to the Treaty area because the ATS is the agreed legislative framework in place for the region. However, the need for designation of protected areas for the conservation of representative Antarctic habitats is recognized in the Protocol on Environmental Protection to the Antarctic Treaty (also known as the Madrid Protocol or Environmental Protocol [http://www.ats.aq/e/ep.htm]). Annex $\mathrm{V}$ to the Protocol describes the Antarctic Protected Area system (for Annex V see http://www.ats.aq/documents/recatt/Att004_e.pdf).

Through this legal instrument, Antarctic Specially Protected Areas (ASPAs), and their associated management plans, were created as the main tools for protecting representative ecosystems.

Results of recent studies call into question the effectiveness of the Annex V legislation at local, regional, and continental scales (Hughes et al. 2013; Pertierra \& Hughes 2013; Shaw et al. 2014). Indeed, contrary to the widely held view that Antarctica is a natural reserve, devoted to peace and science, and therefore fully protected through the ATS, Shaw et al. (2014) describe Antarctica as one of the least protected regions on the planet; only about $1.5 \%$ of its ice-free area is formally protected under the ASPA system. Use of an evidence-based approach to establish biologically meaningful quantitative targets for area protection has not been undertaken for the Antarctic continent as a whole (Svancara et al. 2005). However, the current level of protection is clearly inadequate, and vast regions of Antarctic are devoid of specially protected areas (Terauds et al. 2012; Shaw et al. 2014).

We assessed the current state of protection of Antarctic botanical biodiversity by quantifying the area of existing ASPAs protecting vegetation within each of the ACBRs, and examined the extent of protection of primarily vascular plants and bryophytes within ASPAs with remote sensing techniques that detect green vegetation.

\section{Methods}

We accessed the ASPA management plans online via the Antarctic Treaty Secretariat website (http://www.ats. aq/documents/ATCM37/WW/atcm37_ww002_e.pdf), and obtained the ACBR shape files from the Australian Antarctic Data Centre (https://www1.data. antarctica.gov.au/). High spatial resolution multispectral satellite imagery (with approximately $2-$ to $3-\mathrm{m}$ pixels) of all ASPAs where terrestrial vegetation is included in the respective management plan's Description of Values to be Protected was acquired from the DigitalGlobe QuickBird and WorldView-2 satellite sensors (Fig. 2 and Appendix S1). We did not consider ASPAs protecting only bird colonies, geological features, historic huts, or marine ecosystems. We used the well-established normalized difference vegetation index (NDVI), which is predominantly useful in the detection of green vegetation (Petzold \& Goward 1988; Gates 2003), to assess vegetation cover within each ASPA. Following investigation of a number of different vegetation indices, use of the NDVI was determined to be the best approach. This index cannot be used to detect some species (e.g., dark pigmented lichens or mosses), but other limitations caused by mixed signals due to bare ground, snow, and ice cover, as described by Fretwell et al. (2011), are significantly reduced because of the higher spatial resolution of the satellite imagery we used.

As far as possible, we used satellite images captured from December to March in order to reduce the confounding effect of snow cover, which is greater at other times of the year. The ASPA boundaries were taken from the Antarctic Protected Area database (http://www.ats.aq/devPH/apa/ep_protected.aspx?lang $=\mathrm{e})$. In some cases, corrections were made to ensure the digitized ASPA boundary coincided with features visible in the satellite imagery and the maps in the associated ASPA management plan. Vegetation cover density was 


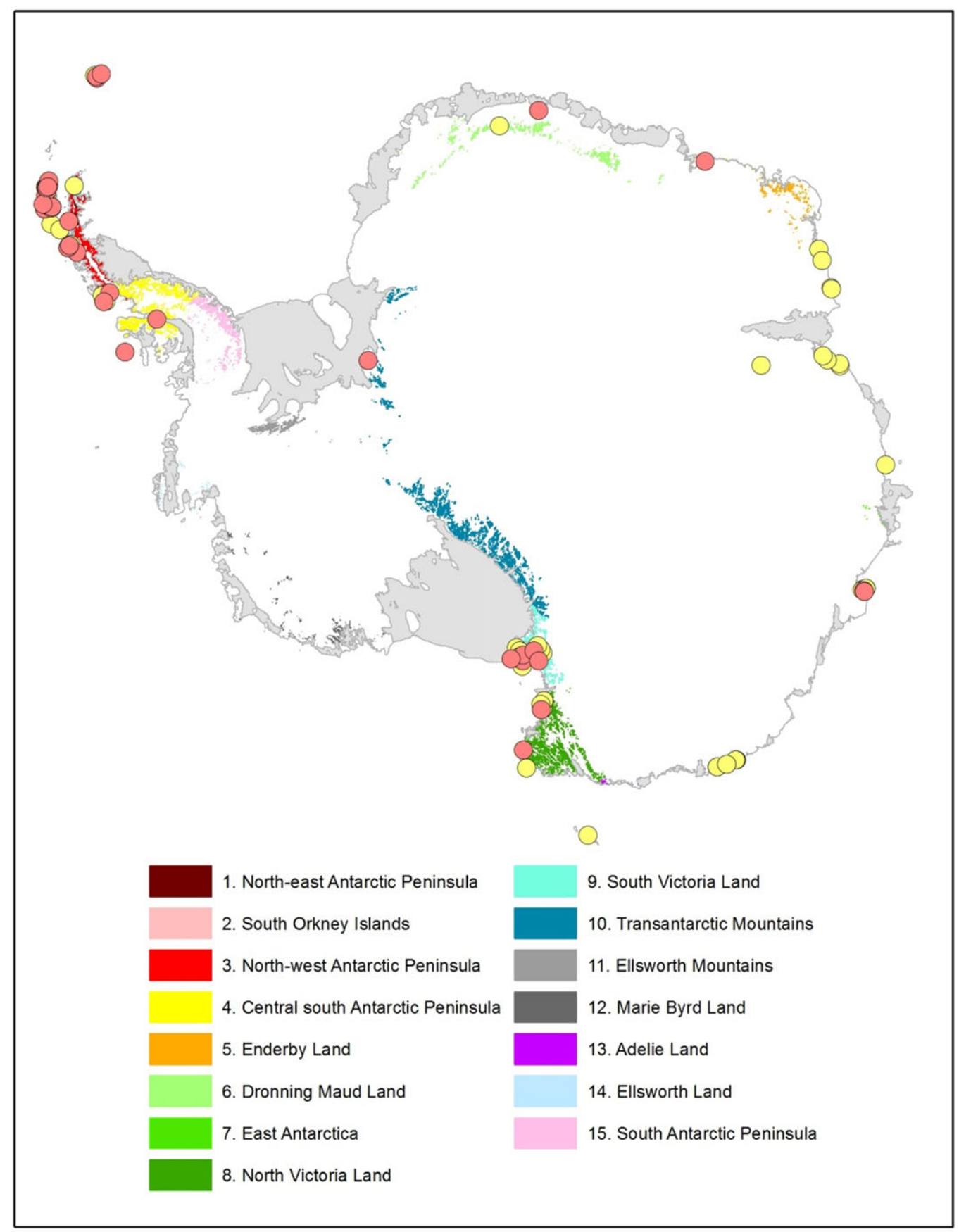

Figure 2. Current network of Antarctic Specially Protected Areas (ASPAs) (red circles, ASPAs protecting vegetation included in this study; yellow circles, ASPAs not included in this study). Antarctic Conservation Biogeographic Regions 1-15 are shown as described by Terauds et al. (2012).

calculated for each ASPA based on the areas of ice-free ground and of vegetated ground within each ASPA.

Where necessary, the satellite data used to derive the vegetation extent were corrected to remove distortions due to terrain elevation. Surface elevation data were obtained from airborne photogrammetry where available; otherwise, we used the global ASTER GDEM (http://asterweb.jpl.nasa.gov/gdem.asp) elevation data set. Data values were converted to reflectance with no atmospheric correction. The quality of the available elevation data differed and in some areas had errors that introduced distortions in the imagery. For some ASPAs, no elevation data exist; therefore, no terrain correction was possible. The area of vegetation cover for each ASPA was based on the area within the ASPA boundary with an NDVI value greater than a set threshold. Values of 
Table 1. Area of vegetated ground protected within the Antarctic Specially Protected Area (ASPA) system.

\begin{tabular}{lccc}
\hline Category & Area $\left(\mathrm{km}^{2)}\right.$ & $\begin{array}{c}\text { As a percentage } \\
\text { of Antarctica }\end{array}$ & $\begin{array}{c}\text { As a percentage of } \\
\text { Antarctic ice-free ground }\end{array}$ \\
\hline All of Antarctica & $14,000,000$ & 100.0000 & - \\
Antarctic ice-free ground & 44,000 & 0.3143 & 100.00 \\
ASPAs protecting terrestrial vegetation & 605.7 & 0.0043 & 1.38 \\
Ice-free ground in ASPAs protecting terrestrial vegetation & 214.5 & 0.0015 & 0.49 \\
Vegetation cover within ASPAs & 16.1 & 0.0001 & 0.04 \\
\hline
\end{tabular}

NDVI range from -1.0 to +1.0 . Here, we considered vegetation was present if the NDVI value was $\geq 0.1$. This threshold was based on cross-comparison with ground data collected during a 2011 hyperspectral airborne campaign carried out over parts of Adelaide Island and islands in Marguerite Bay (west of the Antarctic Peninsula, c. $68^{\circ} \mathrm{S}$ ) and subsequent analyses by Fretwell et al. (2011). This threshold is based on data from a single locality and applicability to the entire continent or more extensively vegetated areas has not been tested, but this location hosts vegetation that is regarded as typical throughout the Antarctic Peninsula and Scotia Arc (e.g., Smith 1984; Smith 1996; Convey \& Smith 1997). Furthermore, the locations of many ASPAs protecting terrestrial areas are in similar geographic settings (in particular, those within the Antarctic Peninsula and Scotia Arc regions, which are all close to the coast), but in situ data for other locations are, as yet, unavailable.

\section{Results}

Of Antarctica's 72 designated ASPAs, the management plans of 33 include macroscopic vegetation among the values to be protected. The ice-free area designated for the protection of vegetation within the entire ASPA network represents $<0.5 \%$ of Antarctica's ice-free ground (Table 1). Six ACBRs (numbers 1, 11, 12, 13, 14, and 15) contained no ASPAs protecting vegetation, and a further six $(5,6,7,8,9$, and 10$)$ included $<0.4 \%$ of their area within an ASPA designated for protection of botanical values (Table 2). The highest percentage of ASPA-protected ice-free ground was within ACBR 2 South Orkney Islands (3.3\%).

The 33 ASPAs we examined covered a combined icefree area of approximately $214.5 \mathrm{~km}^{2}$, of which 16.1 $\mathrm{km}^{2}(7.5 \%)$ were classified as vegetated (Tables 1,2 , Supporting Information). The area of vegetation within each ASPA was highly variable. Number 126 (Byers Peninsula, Livingston Island, South Shetland Islands) contained over $50 \%\left(8.1 \mathrm{~km}^{2}\right)$ of the total area of vegetated ground detected within all 33 ASPAs (Fig. 3). The density of vegetation covering the available ice-free ground also varied (range: 0.004-47.5\%); ASPA 151 (Ardley Island, Maxwell Bay, King George Island), ASPA 133 (Harmony Point, Nelson Island; both in the South Shetland Islands), and ASPA 109 (Moe Island, South Orkney Islands) were

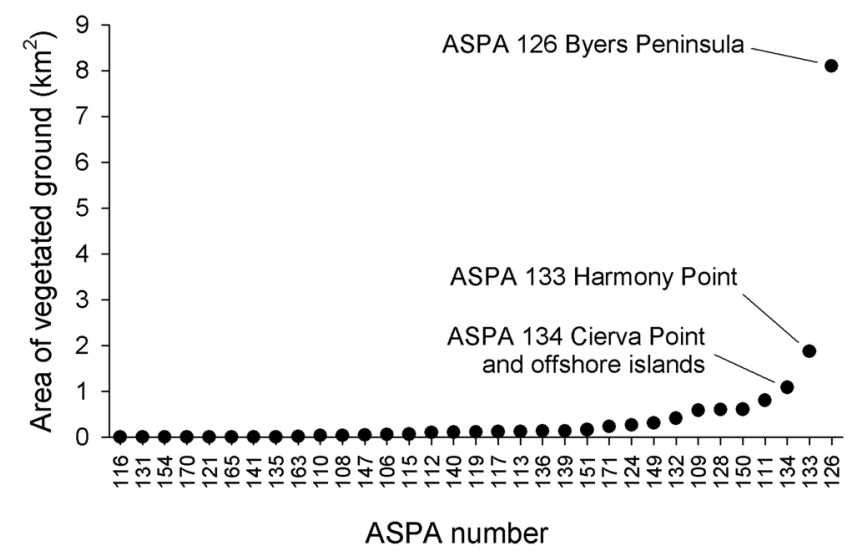

Figure 3. Area of vegetated ground within Antarctic Specially Protected Areas (ASPAs) protecting Antarctic flora detected with satellite remote sensing techniques.

the most densely vegetated ( $>47 \%$ coverage of available ice-free ground).

When the amount of vegetation protected within each of the ACBRs was quantified, there was a clear bias toward protection of habitats in ACBR 3 Northwest Antarctic Peninsula, which contained over $87 \%$ of Antarctica's protected vegetation cover (Table 2, column 9). The ACBR 2 South Orkney Islands contained the second highest area of protected vegetation, almost $9 \%$, whereas the remaining 13 ACBRs contained $<4 \%$ of the total protected vegetation.

\section{Discussion}

Compared with most regions of the planet, Antarctic macroscopic terrestrial vegetation cover is poorly developed and spatially restricted (Laws 1984; Fretwell et al. 2011; Convey et al. 2014). However, biogeographical studies show much regional differentiation in biodiversity across the continent's ice-free areas (e.g., Peat et al. 2007; Convey et al. 2008; Pugh \& Convey 2008), making representative protection an important objective to be achieved by the Antarctic Treaty Consultative Meeting (the governing body established under the ATS). Nevertheless, our analyses showed that designation of terrain for protection of vegetation was nonexistent or accounted for $<0.4 \%$ of the total ice-free area in 12 of the 15 ACBRs. 


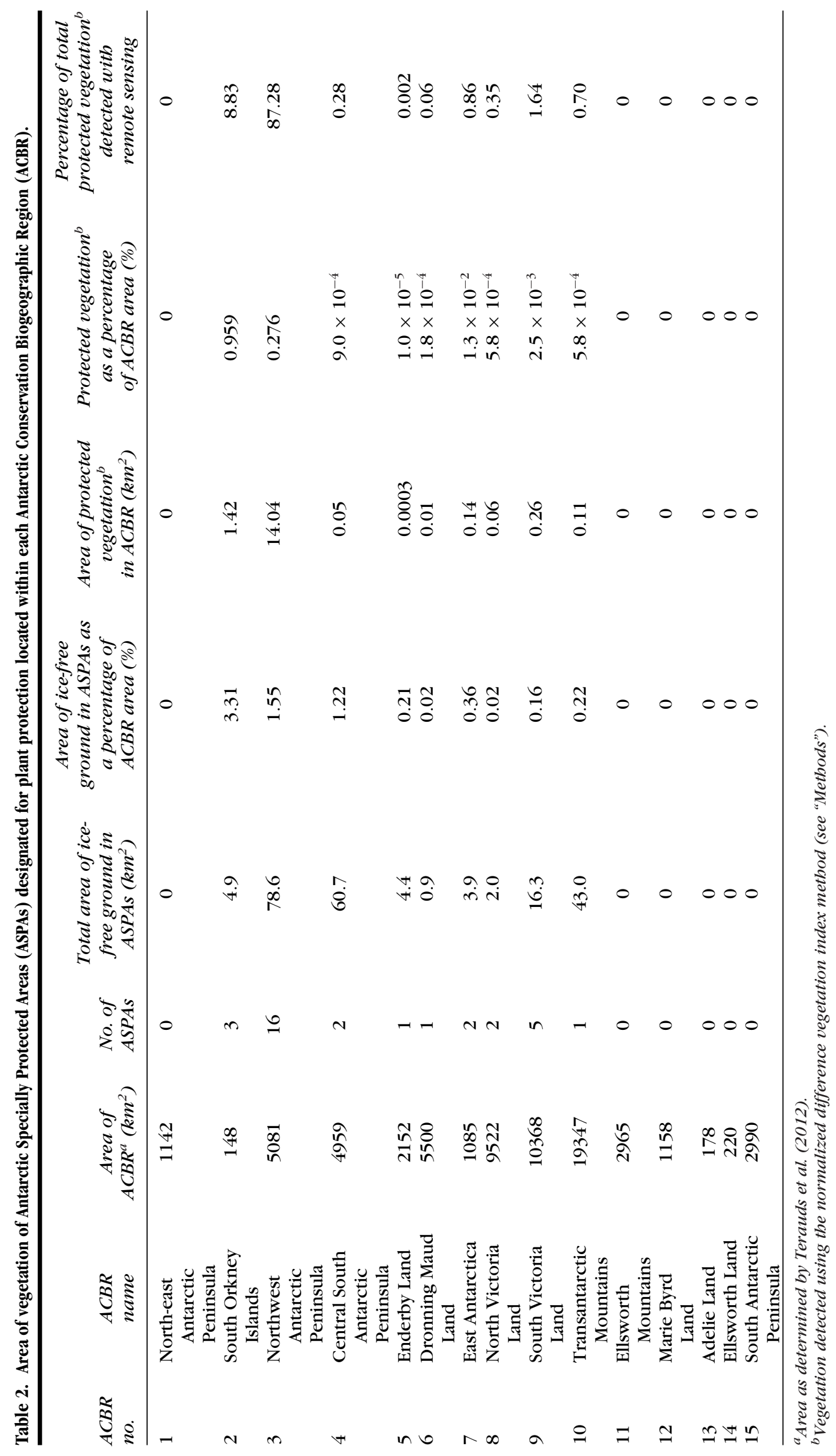


Our remote sensing survey of terrestrial vegetation in all ASPAs designated for plant protection showed that $<16.1 \mathrm{~km}^{2}$ of vegetation cover within the Antarctic continent as a whole was protected-an area that would fit easily within John F. Kennedy International Airport in New York. This highlights the sparseness of Antarctic vegetation; in total there is only $7.5 \%$ vegetation cover of icefree terrain within the ASPAs designated specifically for their unusually high vegetation abundance. More widely, Fretwell et al. (2011), using lower resolution Landsat imagery of the northern Antarctic Peninsula, estimated that $44.6 \mathrm{~km}^{2}(0.086 \%)$ of their study area $\left(74,468 \mathrm{~km}^{2}\right)$ had a probability of vegetation occurrence of over $50 \%$. Together, these studies support the observation of generally low levels of plant cover within Antarctica. However, to date no systematic satellite or ground-based assessment of vegetation cover across Antarctica has been attempted, meaning the proportion of Antarctica's protected vegetation cover has not been objectively estimated.

Given the bias of the NDVI method (as used both here and by Fretwell et al. [2011]) toward the detection of typically green vegetation, such as vascular plants and bryophytes, the extent of communities dominated by species where the chlorophyll signal is masked by pigmentation may not be fully represented (e.g. stands of the moss genus Andreaea, mats of dark cyanobacteria, and many lichen species; see Petzold \& Goward 1988). Such communities are often important in montane and higher latitude continental locations, which may contribute, along with low vegetation densities, to the lower levels of vegetation recorded within continental ACBRs. Development of more sophisticated hyperspectral imaging methods and availability of higher resolution imagery may facilitate future quantification of the spatial coverage of both specific and overall vegetation communities (Shin et al. 2014).

We found that the area of detected vegetated ground currently protected under the ASPA system equated to only $0.04 \%$ of ice-free ground in Antarctica, and 96\% of this protected area fell within the botanically similar ACBR 2 South Orkney Islands and ACBR 3 Northwest Antarctic Peninsula (including the South Shetland Islands) (Peat et al. 2007). In a broader context, the existing ASPA network fails to meet GSPC Target 4 and Aichi Biodiversity Target 11 for all of Antarctica's 15 ecological regions (i.e., ACBRs) (Table 2).

Shaw et al. (2014) showed that Antarctic biodiversity protection is poorly served by the scale and extent of the existing ASPA network and that Antarctica is inadequately protected in relation to global benchmarking. Using methods similar to theirs, but targeting green plant communities with NDVI, we found that Antarctica's botanical values are currently inadequately protected by the ASPA system, both in terms of the quantity of vegetation cover and the representativeness of plant diversity and communities protected across the continent. Our results point to a need for designation of a more rep- resentative network of ASPAs protecting terrestrial vegetated habitats, particularly in ACBRs where no ASPAs currently exist. Like Shaw et al. (2014), we encourage the Antarctic Treaty Parties to take steps to meet the CBD's Aichi Targets. Threats such as climate change, invasive species, and increasing human activity have the potential to negatively affect indigenous flora and biological communities in this ecologically sensitive region (Tin et al. 2009; Hughes \& Convey 2010; Chown et al. 2012). Until the Parties collectively act on their agreed responsibility to maintain Antarctica "as a natural reserve" with the coordinated identification of representative habitats, designation of appropriate protected areas, and active management and enforcement of area management plans, progress will be slow and Antarctic terrestrial habitats and their associated biota will remain at risk.

\section{Acknowledgments}

This article is a contribution to the Scientific Committee on Antarctic Research (SCAR) AntEco (State of the Antarctic Ecosystem) research program and the British Antarctic Survey's Polar Science for Planet Earth core programs Environment Office - Long Term Monitoring and Survey (EO-LTMS) and Biodiversity, Evolution and Adaptation (BEA).

The authors are supported by Natural Environment Research Council core funding to the British Antarctic Survey. We are grateful for financial support from the UK Foreign and Commonwealth Office through the British Antarctic Territory Strategic Project Funding initiative. We also acknowledge the contribution of ITRES and DRDC (Defence Research and Development Canada) to the collection of airborne hyperspectral data used in this study. Satellite imagery for each ASPA examined in this study was acquired by either the Quickbird or WorldView-2 satellites and licensed from DigitalGlobe Inc. The map that shows results of vegetation cover within ASPAs is based on the Antarctic Digital Database (ADD) online mapping infrastructure (Supporting Information). The vegetation data presented here are currently not a formal part of the ADD. We thank P. Fretwell and H. Peat for discussions during this project, O. MartinSanchez for map preparation, and D. Herbert for technical assistance with the website. We also thank 3 anonymous reviewers for their insightful comments.

\section{Supporting Information}

A map showing the ASPA high spatial resolution multispectral satellite imagery and remote sensing analysis is available online at http://www.add.scar. org/aspa_vegetation_pilot.jsp. The authors are solely responsible for the content and functionality of this material. Queries (other than absence of the material) should be directed to the corresponding author. 


\section{Literature Cited}

Bergstrom DM, Chown SL. 1999. Life at the front: history, ecology and change on Southern Ocean islands. Trends in Ecology and Evolution 14:472-477.

Braun C, Hertel F, Mustafa O, Nordt A, Pfeiffer S, Peter H-U. 2014. Environmental assessment and management consequences of the Fildes Peninsula Region. Pages 169-191 in Tin T, Liggett D, Maher P, Lamers M, editors. The future of Antarctica: human impacts, strategic planning and values for conservation. Springer, Dordrecht.

Chown SL, Convey P. 2007. Spatial and temporal variability across life's hierarchies in the terrestrial Antarctic. Philosophical Transactions of the Royal Society of London, Series B. 362:2307-2331, doi: 10.1098/rstb.2006.1949.

Chown SL, et al. 2012. Challenges to the future conservation of the Antarctic. Science 337:158-159.

Convey P. 2013. Antarctic ecosystems. Pages 179-188 in Levin SA, editor. Encyclopedia of biodiversity, Volume 1. 2nd edition. Elsevier, San Diego.

Convey P, Smith RIL. 1997. The terrestrial arthropod fauna and its habitats in northern Marguerite Bay and Alexander Island, maritime Antarctic. Antarctic Science 9:12-26.

Convey P, Gibson JAE, Hillenbrand C-D, Hodgson DA, Pugh PJA, Smellie JL, Stevens MI. 2008. Antarctic terrestrial life-challenging the history of the frozen continent? Biological Reviews 83:103-117, doi: 10.1111/j.1469-185X.2008.00034.x.

Convey P, Stevens MI, Hodgson DA, Smellie JL, Hillenbrand C-D, Barnes DKA, Clarke A, Pugh PJA, Linse K, Cary SC. 2009. Exploring biological constraints on the glacial history of Antarctica. Quaternary Science Reviews 28:3035-3048.

Convey P, Chown SL, Clarke A, Barnes DKA, Bokhorst S, Cummings V, Ducklow HW, Frati F, Green TGA, Gordon S, et al. 2014. The spatial structure of Antarctic biodiversity. Ecological Monographs 84:203-244, doi: 10.1890/12-2216.1.

Favero-Longo SE, Cannone N, Worland MR, Convey P, Piervittori R, Guglielmin M. 2011. Changes in lichen diversity and community structure with fur seal population increase on Signy Island, South Orkney Islands. Antarctic Science 23:65-77, doi:10.1017/S0954102010000684.

Fowbert JA, Smith RIL. 1994. Rapid population increases in native vascular plants in the Argentine Islands, Antarctic Peninsula. Arctic and Alpine Research 26:290-296.

Frenot Y, Chown SL, Whinam J, Selkirk PM, Convey P, Skotnicki M, Bergstrom DM. 2005. Biological invasions in the Antarctic: impacts and implications. Biological Reviews 80:45-72.

Fretwell PT, Convey P, Fleming AH, Peat HJ, Hughes KA. 2011. Detecting and mapping vegetation distribution on the Antarctic Peninsula from remote sensing data. Polar Biology 34:273-281.

Gates DM. 2003. Biophysical ecology. Courier Dover Publications, New York.

Hughes KA, Convey P. 2010. The protection of Antarctic terrestrial ecosystems from inter and intra-continental transfer of nonindigenous species by human activities: a review of current systems and practices. Global Environmental Change 20:96-112.

Hughes KA, Pertierra LR, Walton DWH. 2013. Area protection in Antarctica: How can conservation and scientific research goals be managed compatibly? Environmental Science and Policy 31:120-132.

Laws RM, editor. 1984. Antarctic ecology. Volume 1. Academic Press, London.

Levy J. 2013. How big are the McMurdo Dry Valleys?-Estimating icefree area using Landsat image data. Antarctic Science 25:119-120.

Ochyra R, Smith RIL, Bednarek-Ochyra H. 2008. The illustrated moss flora of Antarctica. Cambridge University Press, Cambridge.

$\varnothing v$ stedal DO, Smith RIL. 2001. Lichens of Antarctica and South Georgia: a guide to their identification and ecology. Cambridge University Press, Cambridge.
Peat HJ, Clarke A, Convey P. 2007. Diversity and biogeography of the Antarctic flora. Journal of Biogeography 34:132-146, doi: 10.1111/j.1365-2699.2006.01565.x.

Pertierra LR, Hughes KA. 2013. Management of Antarctic Specially Protected Areas: permitting, visitation and information exchange practices. Antarctic Science 25:553-564.

Petzold DE, Goward SN. 1988. Reflectance spectra of subarctic lichens. Remote Sensing of Environment 24:481-492.

Pisa S, Biersma EM, Convey P, Patiño J, Vanderpoorten A, Werner O, Ros RM. 2014. The cosmopolitan moss Bryumargenteum in Antarctica: Recent colonization or in situ survival? Polar Biology 37:14691477.

Pugh PJA, Convey P. 2008. Surviving out in the cold: Antarctic endemic invertebrates and their refugia. Journal of Biogeography 35:21762186, doi: 10.1111/j.1365-2699.2008.01953.x.

Shaw JD, Terauds A, Riddle MJ, Possingham HP, Chown SL. 2014. Antarctica's protected areas are inadequate, unrepresentative, at risk. PLoS Biology: e1001888, doi: 10.1371/journal.pbio.1001888.

Shin J-I, Kim H-C, Kim S-I, Hong SG. 2014. Vegetation abundance on the Barton Peninsula, Antarctica: estimation from high-resolution satellite images. Polar Biology 37:1579-1588.

Smith RIL. 1994. Vascular plants as bioindicators of regional warming in Antarctica. Oecologia 99:322-328.

Smith RIL. 1996. Terrestrial and freshwater biotic components of the western Antarctic Peninsula. Pages 15-59 in Ross RM, Hofmann EI, Quetin LB, editors. Foundations for ecological research west of the Antarctic Peninsula. Antarctic Research Series 70. American Geophysical Union, Washington, D.C.

Smith RIL. 2003. The enigma of Colobanthus quitensis and Deschampsia antarctica in Antarctica. Pages 234-239 in Huiskes AHL, Gieskes WWC, Rozema J, Schorno RML, van der Vies SM, Wolff WJ, editors. Antarctic biology in a global context. Backhuys Publications, Leiden.

Smith RIL. 1984. Terrestrial plant biology of the sub-Antarctic and Antarctic. Pages 61-162 in Laws RM, editor. Antarctic ecology, vol 1. Academic Press, London.

Smith RIL. 1988. Destruction of Antarctic terrestrial ecosystems by a rapidly increasing fur seal population. Biological Conservation 45:55-72.

Svancara LK, Brannon R, Scott JM, Groves CR, Noss RF, Robert LP. 2005. Policy-driven versus evidence-based conservation: a review of political targets and biological needs. BioScience 55:989995.

Terauds A, Chown SL, Morgan FJ, Peat H, Watts DJ, Keys H, Convey P, Bergstrom DM. 2012. Conservation biogeography of the Antarctic. Diversity and Distributions 18:726-741.

Tin T, Lamers M, Liggett D, Maher PT, Hughes KA. 2014. Setting the scene: human activities, environmental impacts and governance arrangements in Antarctica. Pages 1-24 in Tin T, Liggett D, Maher P, Lamers M, editors. The future of Antarctica: human impacts, strategic planning and values for conservation. Springer, Dordrecht.

Tin T, Fleming ZL, Hughes KA, Ainley DG, Convey P, Moreno CA, Pfeiffer S, Scott J, Snape I. 2009. Impacts of local human activities on the Antarctic environment. Antarctic Science 21:3-33.

United Nations Environment Programme. 2010 $a$. Decision adopted by the Conference of the Parties to the Convention on Biological Diversity at its Tenth Meeting. X/17. Consolidated update of the Global Strategy for Plant Conservation 2011-2020. United National Environment Programme Convention on Biological Diversity. Available at http://www.cbd.int/decision/cop/default.shtml?id=12283 (accessed December 14, 2014).

United Nations Environment Programme. 2010b. Decision adopted by the Conference of the Parties to the Convention on Biological Diversity at its Tenth Meeting. X/2. The Strategic Plan for Biodiversity 2011-2020 and the Aichi Biodiversity Targets.United National Environment Programme Convention on Biological Diversity. Available at http://www.cbd.int/sp/targets/ (accessed December 2014). 